\title{
【特 集：廃棄物と金属回収】
}

\section{製品設計におけるリサイクル性とライフサイクルアセスメント}

\author{
永田勝 也 *
}

【要 旨】環境亡資源の保全から廃衰物再資源化に対する要請が強まり，国民全体で廃棄物の再資源化 に取り組む資源循環型社会の構築が急がれている。こうした情勢にあってリサイクル性を考慮した製品 作りが望まれている。ここでは, まずリサイクルシステムの分類と特徴についてふれ，その動向や望ま しい方向に関して述べた。さらにリサイクル設計に当たっての要点を考察するとともに，その評価法の いくつかの例を提示した。また，現在注目を集めているライフサイクルアセスメントに関して海外の実 施あるいは提案例を紹介し, その重要性を指摘した。最後にリサイクルを含めた環境保全型製品設計に 関連する課題を整理した。

キーワード：製品設計，リサイクル，ライフサイクルアセスメント，物質回収，製品アセスメント

\section{1. まえがき}

近年, 生活レベルの向上にともなって廃棄物の排出量 が増加する一方, 地球環境問題に対する配慮から資源の 有効活用が強く求められている。こうした情勢から国民 全体で廃棄物の減量化・再資源化に取り組むリサイクル 社会の構築が抜本的対策として掲げられ，いわゆる「リ サイクル法」の制定や「廃棄物処理法」の改正へ之展開 するに至り, また最近では「産廃施設整備促進法」「省 エネ・リサイクル支援法」の成立を促した。

廃棄物をとりまくこうした状況は, わが国のみあので はなく，先進諸国で共通した現象となっている。ドイッ ではすでに包装材（飲料のビンやカンを含む）について の規制が実施され，製造業者や販売業者に対してその回 収・再資源化の義務付けが行われている。こうした規制 を廃自動車や廃家電製品・電子機器, さらには新聞等の 印刷物, 建設廃材などに対して拡大させようとの動きが 報じられている。

わが国でも「リサイクル法」では, 再生資源としての 利用促進がとくに必要な第 1 種製品として,すでに自動

原稿受付 1993.9.14

* 早稲田大学理工学部 機械工学科教授 連絡先 : $\mathbf{T} 169$ 東京都新宿区大久保 3-4-1
車や家電製品が指定され, さらに今年度に入ってニカド 電池を使用する電動工具等 16 品目が追加された。こう した製品にあっては, リサイクルに有利な材料選択や構 造の工夫, 分別・分離への配慮等を設計時に事前評価す ることが求められている。

\section{2.リサイクルシステムのあり方}

従来の産業・社会体系は処女資源 $\rightarrow$ 素材 $\rightarrow$ 加工・生産 使用 $\rightarrow$ 廃棄という一方通行の形態をとっていた。資源 リサイクルは廃衰から, あるいは廃棄に至る中間過程か ら素材や原料に戻すという，いわゆる負のプロセス（還 元プロセス, 静脈産業）をこれに付加するあのであり, 循環体系を形成させようとするものである。

エントロピーの概念を用いて, リサイクルシステムの あり方について考えてみる。エントロピーは, Clausiusによって導入され，過程の不可逆性の尺度を表すむの と理解され，また Boltzmannによって統計的考察では, 無秩序さの度合を示すすのとして説明されている。不可 逆過程はエントロピーを増大させ, また確率の大きな状 態への移行は同じくエントロピーの增大につながる。

リサイクルの系統は図 1 に示すようにまとめることが できよう”。ここでは，資源 $\rightarrow$ 生産 $\rightarrow$ 使用 $\rightarrow$ 廃棄のプロ セスは生産・排出源としてまとめて示してある。自家処 


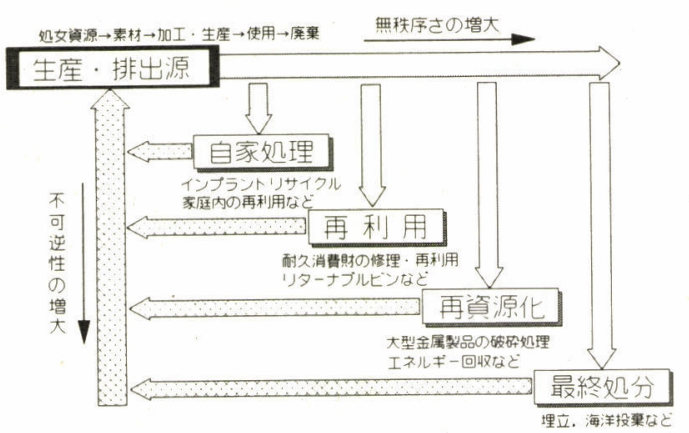

図 1 廃棄物循環システム

理（インプラントリサイクリング）は, 生産工程の途中 で発生する産業廃棄物を, その性状に合わせてできるだ け短いサーキットで前の工程に戻すものである。再利用 は家電製品や自動車等でみられるような一部の部品交 換・修理後の利用や, いわゆるリターナブルビン（一升 ビン，ビールビンなど）の例が上げられる。

再資源化は図 2 に示されるように, 部品回収から材料 あるいは素材としてのリサイクル, さらには他産業での 原料としての使用などに分類することができる（この図 ではエネルギー回収む含めてある)。

材料とは素材にある程度の機能と形態が付与されたも のである。材料や素材としてのリサイクルには元の部材 として使用可能な場合（クローズドリサイクルと呼ぶこ とがある）とグレードの落ちる部材や製品に使用できる 場合（オープンリサイクル）がある。リサイクル可能な ものでむ後者に属するあのが多く, このように順次ラン クを落しながらのリサイクルをカスケード利用と呼ぶこ とあある。材料としてのリサイクルのうち, 最近話題に なっている Bumper to Bumper のプラスチックリサイ クルは前者の例であり, シートクッション等のマッド ガードやカッペットアンダーレイへの再生は後者に当た る。

古紙, 空カン, ワンウェイビンのリサイクルや都市ご み中からの鉄, 紙類の回収, 家電製品や自動車等金属系 大型廃棄物の破砕・選別処理等は素材としてのリサイク ルの代表的な例である。廃自動車やスチールカンなどか ら回収されたくず鉄はグレードの落ちる建築用の棒鋼な どに再生される。最近, 重縮合型プラスチック（PET 等) では，モノマーまで戻してのリサイクルも注目され ており,このようなものをケミカルリサイクルと呼ぶが, この場合には元の部材に使用できる可能性が高まる。

図には同一製品あるいは同一産業内での利用が図れる 範囲と, 他製品あるいは他産業, 山元還元に回される場 合の範囲を示した。

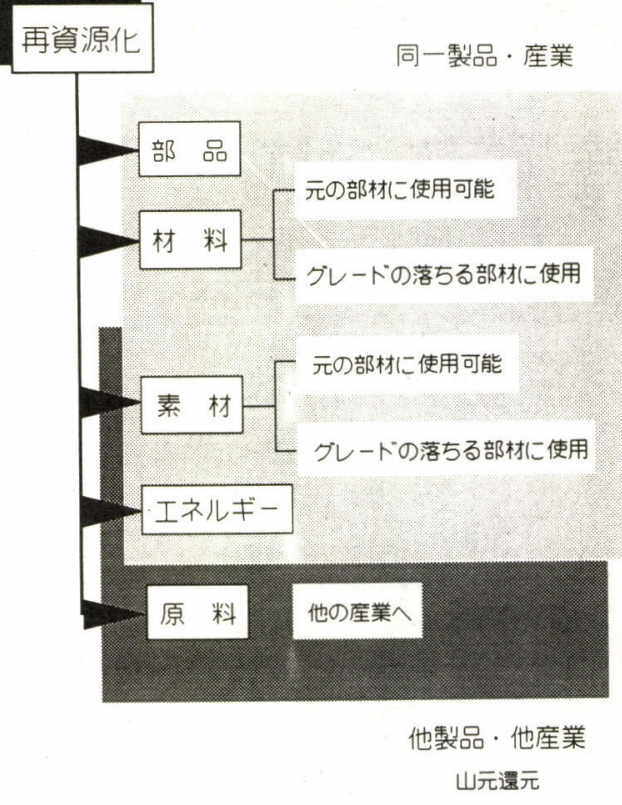

図 2 再資源化の内容

また, 埋立を中心とした最終処分は自然の物質循環系 を利用するサーキットである。

これらのリサイクルシステムでは, 生産・排出源にお ける処女資源 $\rightarrow$ 使用 $\rightarrow$ 廃棄の循環プロセスへの還流点は, 外側のサーキットほど処女資源側に近くなる。自家処理, 再利用, 再資源化, 最終処分のプロセスは, 多くの処理 工程を含む。この処理工程は, 破砕・選別にしろ, 回 収・輸送にしろ不可逆過程であり, 秩序だった（分別さ れた）再生原料を得るには，一般的にその工程が増える ほど, すなわち外側サーキットほよ゙エントロピーの増大 するシステムとなり, 元に戻すために消費されるエネル ギーの増加を招くことになる。

また見方を変えれば，生産・排出源から負のプロセス への還流点では, 外側のサーキットほよ゙, その回収物の 無秩序さは, 他の廃衰物との混在により増大しており, エントロピーの高い状態になっている。このことが上述 の低エントロピーの再生原料の生産に多くのエネルギー を必要とすることにつながる。このように物質リサイク ルでは, できるだけ短いサーキットで処理することが肝 要であり, 古紙や空ビン, 空カン等の回収や分別収集等 のような, 排出源である家庭での低エントロピー化の努 力や負のプロセスにおける流通経路の整備も重要なこと である。

自動車や家電製品等の複雑な工業製品の再資源化プロ セスでは一般に, 分離/解体一破砕一選別の工程が採用 されることが多い。破砕は材料別の仕分けのため, いっ 
たんきわめて無秩序な状態にする操作であり，エントロ ピーの考えからいえば合理的でない。最近こうした製 品の再資源化に当たって分離/分解が注目されているの む, 以上の理由が背景にあると理解されよう。

\section{3. リサイクルと製品設計 ${ }^{2}$}

工業製品の場合,「設計」という概念がカバーする範 囲は広く, また定義むかなりあいまいである。製品「設 計」をニーズの把握から製造・販売に至る過程の中で, 時間軸に沿って次のように分類するのが一般的のようで ある。

時間軸に沿った見方

(1) 初期設計 (予備設計, 概念設計)

(2) 詳細設計（基本設計）

(3) 生産設計 (詳細設計, 細部設計)

この前段には, その製品に対するニーズ, 目標の設定, 調查等の構想的な領域がある。これに対して，あまり適 切ではないが,ここで空間軸と呼ぶもう一つの軸に沿っ た「設計」が重ねられる。空間軸の「設計」は，そのウ エイトは変化するむのの, 常に時間軸の各種「設計」の 中で意識され，検討されるむのである。

空間軸に沿った見方

(1) 素材設計

(2) 機能設計

(3) 形態設計

さらに, これら二つの軸に沿った各種「設計」は, 経 済性之環境性（文化的，社会的，政治的，宗教的等の “環境”に投入された時のインパクト）の枠組みの中で の制約を受けている。製品が廃棄物になったときの処理 性・再資源化性は, この環境性における, かなり比重の 高い因子であって, 今後これまで以上に, その重要性が 認識されるべきものである。以上を図示したのが図 3 で ある。

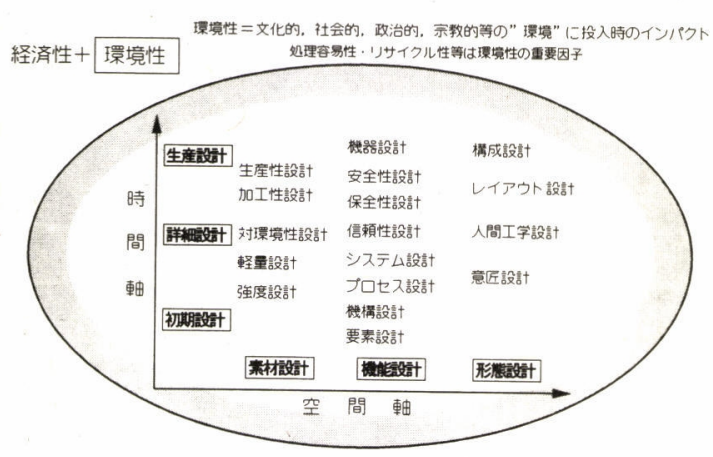

図 3 製品設計における時間軸・空間軸と環境性

\section{4. リサイクル製品設計の要点}

リサイクル型（低エントロピー）製品として設計する 上での要点は, 不可逆過程の程度の縮小と無秩序さの改 善, すなわち統一化, 統合化, 簡素化, 省エネ化であり, 具体的には素材, 部品, 製品の各レベルにおいて図 4 に 示すような対応が考えられよう。

すなわち素材レベルでは, 使用物質の量を減じること, 可能な限り同一の素材を用いること, 混合しても再資源 化に支障ない素材の組合せを選ぶこと, 製品内にあって 同一素材部を偏在させること，再生可能材料を使用する ことなどである。

また部品レベルにあっては, 再利用やリサイクル処理 の容易性から少数化 (モジュール化), 規格化, 標準化 やできるだけ分離させやすい結合方法の採用が望まれる。

さらに製品レベルでは, 部品の統合によって再利用や 再資源化が可能な部分を取り出しやすくするとともに, 解体の方向性への配慮や使用工具の低減, 接合箇所の減 少やその方法の改善を通じて, できるだけ解体しやすく することが重要である。解体しやすい接合方法としては スナップフィットが注目されており，デュポン社ではそ の設計のための支援コンピュータープログラムを販売し ている。このほか, リサイクル可能なものにはその素材 がわかるようにマーキングすること, 輸送・運搬が容易 なように大型の製品にあっては分割できる構造とするこ と, 破砕・選別・焼却といった現在のリサイクル処理に 適するように難破䂶部品を事前に取り出しやすくしたり， 焼却の際に二次污染物質が発生しないような配慮が必要 である。以上の評価項目を整理したのが，表 1 である。

こうした低エントロピー化の方策はリサイクルのみに 寄与するむのでなく, 従来からの目標であった設計・生 産における効率化にも貢献するむのが多い。たとえば, モジュール設計・生産方式は組立作業性の改善や生産 リードタイムの短縮, 自動化・品質保証での有利性から 最近注目されており, また部品やユニットの規格化・標

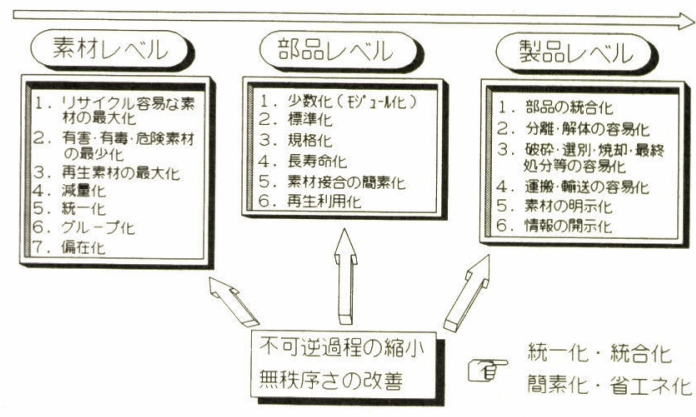

図 4 低エントロピー製品設計の要点 
表 1 低エントロピー製品設計における各レベルの評価項目例

\begin{tabular}{|c|c|c|c|}
\hline \multicolumn{2}{|c|}{ レベル } & 評 価 項 目 & 備 \\
\hline \multicolumn{2}{|c|}{$\begin{array}{l}\text { 素 } \\
\text { 材 } \\
\text { レ } \\
\text { ベ } \\
\text { ル }\end{array}$} & $\begin{array}{l}\text { リサイクル容易な素材の比率 } \\
\text { 有害・有毒・危除物質の比率 } \\
\text { 再資源化・中間処理阻害物質の比率 } \\
\text { 再生素材の比率 } \\
\text { 減量化の考慮 } \\
\text { 種類統一化の考虑 } \\
\text { 偏在化の考慮 }\end{array}$ & $\begin{array}{l}\text { 高低, 阻害材比率等 } \\
\text { 高低 } \\
\text { 高低 } \\
\text { 高低 } \\
\text { 大小 } \\
\text { 大小, グループ化の対応等 } \\
\text { 大小 } \\
\end{array}$ \\
\hline \multicolumn{2}{|c|}{$\begin{array}{l}\text { 部 } \\
\text { 品 } \\
\text { レ } \\
\text { ベ } \\
\text { ル }\end{array}$} & $\begin{array}{l}\text { 少数化（モジュール化）の考慮 } \\
\text { 標準化の章慮 } \\
\text { 規格化の考慮 } \\
\text { 長寿命化の考慮 } \\
\text { 素材接合の簡素性 } \\
\text { 再生部品の活用 }\end{array}$ & $\begin{array}{l}\text { 大小 } \\
\text { 大小 } \\
\text { 大小 } \\
\text { 大小 } \\
\text { 大小, 複合材の多宣等 } \\
\text { 大小 }\end{array}$ \\
\hline \multirow[b]{3}{*}{$\begin{array}{l}\text { 製 } \\
\text { 品 } \\
\text { レ }\end{array}$} & 葆 & $\begin{array}{l}\text { 長寿命化の考虑 } \\
\text { 保守 (部品交換等) の容向性の考虑 }\end{array}$ & $\begin{array}{l}\text { 大小 } \\
\text { 大小 } \\
\end{array}$ \\
\hline & 巣回 & $\begin{array}{l}\text { 運搬・輸送等の容易性 } \\
\text { 運搬・輸送等の安全性 }\end{array}$ & $\begin{array}{l}\text { 易難 } \\
\text { 安全・不安 } \\
\end{array}$ \\
\hline & $\begin{array}{l}\text { 分 } \\
\text { 離 } \\
\dot{\text { 解 }} \\
\text { 体 }\end{array}$ & $\begin{array}{l}\text { 部品の統合化 (交換・変更等) の考虑 } \\
\text { 部品結合の簡素化 (少数化) の考虑 } \\
\text { 部品結合方法の簡易性 } \\
\text { 使用工具の種類 } \\
\text { 解体の方向性の考慮 } \\
\text { 解体時の安全性の考慮 } \\
\text { 大型部品の分離容易性 } \\
\text { 再利用可能部品の分離容易性 } \\
\text { 処理困難部品の分離容易性の考慮 } \\
\text { 有害・有毒・危険部品の分離容易性 }\end{array}$ & $\begin{array}{l}\text { 大小 } \\
\text { 大小 } \\
\text { はめ込み, ボルト, 溶接等 } \\
\text { 多少, 特殊工具の使用等 } \\
\text { 大小 } \\
\text { 大小 } \\
\text { 易難 } \\
\text { 易難 } \\
\text { 大小 } \\
\text { 易難 } \\
\end{array}$ \\
\hline \multirow[t]{3}{*}{$\widetilde{n}$} & 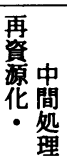 & $\begin{array}{l}\text { 破砕の容易性 } \\
\text { 破砕時の安全性 } \\
\text { 選別の容易性 } \\
\text { 焼却の容易性 } \\
\text { 二分公害防止の容易性 }\end{array}$ & $\begin{array}{l}\text { 易難, 対応装置の内容等 } \\
\text { 安全・不安 } \\
\text { 易難, 対応装膡の内容等 } \\
\text { 装膡の内容等 } \\
\text { 易難, 装膡の内容等 } \\
\end{array}$ \\
\hline & $\begin{array}{l}\text { 最 } \\
\text { 㛷 } \\
\text { 分 }\end{array}$ & $\begin{array}{l}\text { 最終処分の容易性 } \\
\text { 最終処分量の減量化の考虑 } \\
\text { 有害物質の溶出性 } \\
\text { 地盤安定性 }\end{array}$ & $\begin{array}{l}\text { 処理の有無 } \\
\text { 大小 } \\
\text { なし, 大小 } \\
\text { 大小 } \\
\end{array}$ \\
\hline & そ & $\begin{array}{l}\text { 素材の明示 } \\
\text { 垐装・㘝刷の影䈏 } \\
\text { 再資源化・処理処分等の情報の開示 }\end{array}$ & $\begin{array}{l}\text { 実施状況等 } \\
\text { 有用, なし，大小 } \\
\text { 実施状況等 }\end{array}$ \\
\hline
\end{tabular}

準化も設計や部品管理の負担軽減, 生産効率の向上など に寄与できるあのとして取り組みが進展している。

リサイクル法で第 1 種製品に指定された家電や自動車 では, わが国においてあ各企業でリサイクル製品設計の 実施の動きが見られ，こうした設計思想に基づいた製品 あ販売されるようになってきた。また海外でも欧米，と くにヨーロッパでは, リサイクル性を考慮した製品設計 が積極的に研究されており，とくに解体等に配慮する DFD (Design for Disassembly ${ }^{3)}$ ), DOD (Disassembly-Oriented Design ${ }^{4)}$ ) などが注目を集めてい る。これらにおけるリサイクル設計に当たっての考慮点 は, 前掲の表 1 でほとんど網羅されていると考えてよい。

\section{5 . リサイクル製品設計の評価法}

リサイクル製品設計を実施している企業では，表 1 に
示した評価項目を考慮し，これまでの製品より優れたす のを作る努力をしているが，その定量的な評価法には， まだ定まったものがない。

一つの方法としては, 素材構成をべースにするすのが ある。次式に示されるように, 情報理論のエントロピー 概念を用いて, 構成素材の混在の程度（無秩序さ）を統 一した基準とするあのである。

$$
\begin{aligned}
S_{M}=-\Sigma M_{i} \log M_{i} \\
S_{M}: \text { 構成素材エントロピー } \\
M_{i}: \text { 材料の重量割合 }
\end{aligned}
$$

図 5 に家電製品の素材構成と構成素材エントロピーを 示す ${ }^{1)}$ 。冷蔵庫や洗濯機は構成素材エントロピーが低く テレビやステレオ等は高い。このエントロピーと再資源 化率の関係 ${ }^{5)}$ を図 6 に示すが, これからあ構成素材エン 


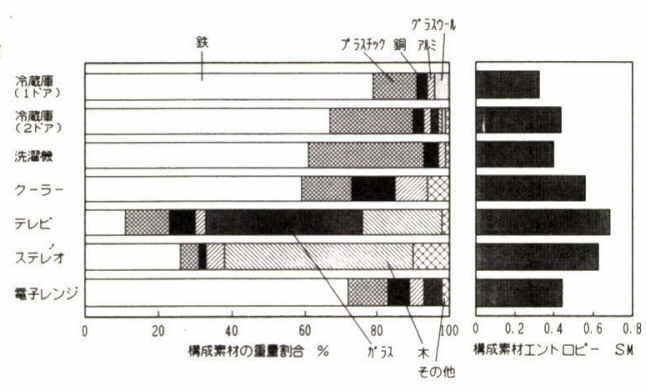

図 5 家電製品の素材構成之構成素材エントロピー（昭 和57年度）

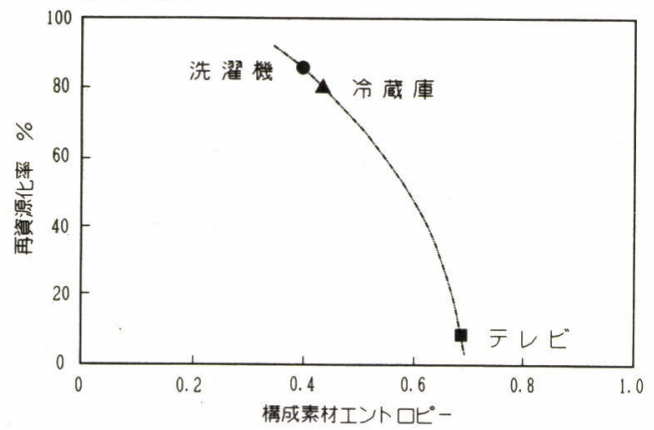

図 6 構成素材エントロピーと再資源化率（家電製品 昭和 57 年度）

表 2 結合状態に着目したリサイクル性評価

\begin{tabular}{|c|c|c|c|}
\hline & 品 & 全自動洗濯機 & 二槽式洗䍜機 \\
\hline \multirow{4}{*}{$\begin{array}{l}\text { 結 合 } \\
\text { 方式 }\end{array}$} & は め 込 み & 31 & 51 \\
\hline & ボルト・ねじ & 29 & 31 \\
\hline & 接着 - 溶 接 & 4 & 7 \\
\hline & 計 & 64 & 89 \\
\hline \multicolumn{2}{|c|}{ 結合評価指数 P } & 134 & 172 \\
\hline
\end{tabular}

$\mathrm{P}=\mathrm{a}_{\mathrm{F}} \Sigma \mathrm{F}+\mathrm{a}_{\mathrm{V}} \Sigma \mathrm{B}+\mathrm{a}_{\mathrm{B}} \Sigma \mathrm{W}$

$\mathrm{a}_{\mathrm{F}}=1$ (はめ込み)

$a_{\mathrm{v}}=3$ (ポルト・ねじ)

$\mathrm{a}_{\mathrm{B}}=5$ (溶接・接着)
トロピーが低いほど再資源化が容易であることがわかる。 解体時の使用工具に対して上記と同様に工具エントロ ピーとして評価することもできる。

また, 分解・解体を中心にした評価方法としては図 7 に示すように, 解体手順を整理し, 結合解除容易性を評 点（はめこみ：1点, ボルト・ネジ等： 3 点, 溶接・接 着： 5 点）として設定して, 解体順序にしたがって合算

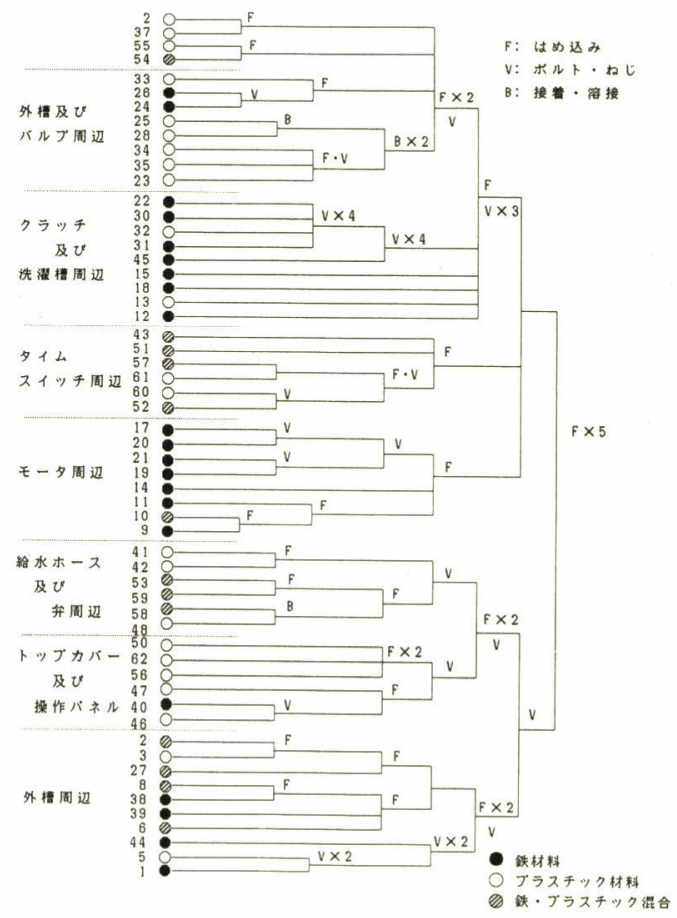

図 7 全自動洗濯機の結合状態

表 3 分離 / 解体性能の評価法

\begin{tabular}{|c|c|c|c|}
\hline G & 性 & 評点 & 例 \\
\hline 1 & 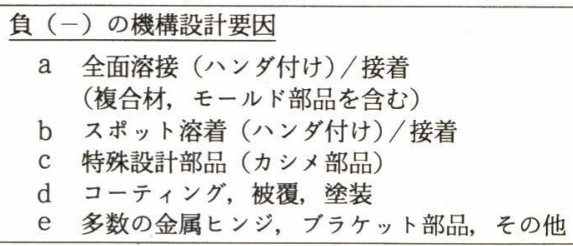 & $\begin{array}{l}-5 \\
-4 \\
-3 \\
-2 \\
-1\end{array}$ & $\begin{array}{l}\text { パッテリー, ラミネート } \\
\text { バッテリー } \\
\text { タンパーブルーフ } \\
\text { 装飾塗装, ラベル }\end{array}$ \\
\hline 2 & $\begin{array}{ll}\text { 正 (+) } & \text { の機構設計要因 } \\
\text { a } & \text { 再資源化可能材料の選択 } \\
\mathrm{b} & \text { 材料表示 } \\
\mathrm{c} & \text { 材料の統一化 } \\
\mathrm{d} & \text { 部品の標準化 } \\
\mathrm{e} & \text { 簡易組立設計 } \\
& \text { f } \\
\text { f 機能性のある素材の選択 } \\
\end{array}$ & $\begin{array}{l}+5 \\
+4 \\
+3 \\
+2 \\
+1 \\
+1\end{array}$ & $\begin{array}{l}\text { 熱可塑性樹脂 } \\
\text { リサイクルマーク } \\
\text { ネジドメ,フィットイン } \\
\text { スナップフィット } \\
\text { 素材自身によるEMCシールド化 }\end{array}$ \\
\hline 3 & $\begin{aligned} & \text { 分離/解体での使用工具 } \\
& \mathrm{a} \text { 汎用工具 } \\
& \mathrm{b} \text { 簡易電動工具 } \\
& \mathrm{c} \text { 破壊工具 } \\
& \mathrm{d} \text { 特殊工具 } \\
& \mathrm{e} \text { 破壊装置 }\end{aligned}$ & $\begin{array}{l}+5 \\
+3 \\
+1 \\
-3 \\
-5\end{array}$ & $\begin{array}{l}\text { ドライバー, ニッパー, ペンチ } \\
\text { カットグライダー, ドリル } \\
\text { ハンマー, タガネ, ドリル } \\
\text { ハンダゴテ, インチ工具 } \\
\text { プレス, 電動カッター, クラッシャー }\end{array}$ \\
\hline
\end{tabular}




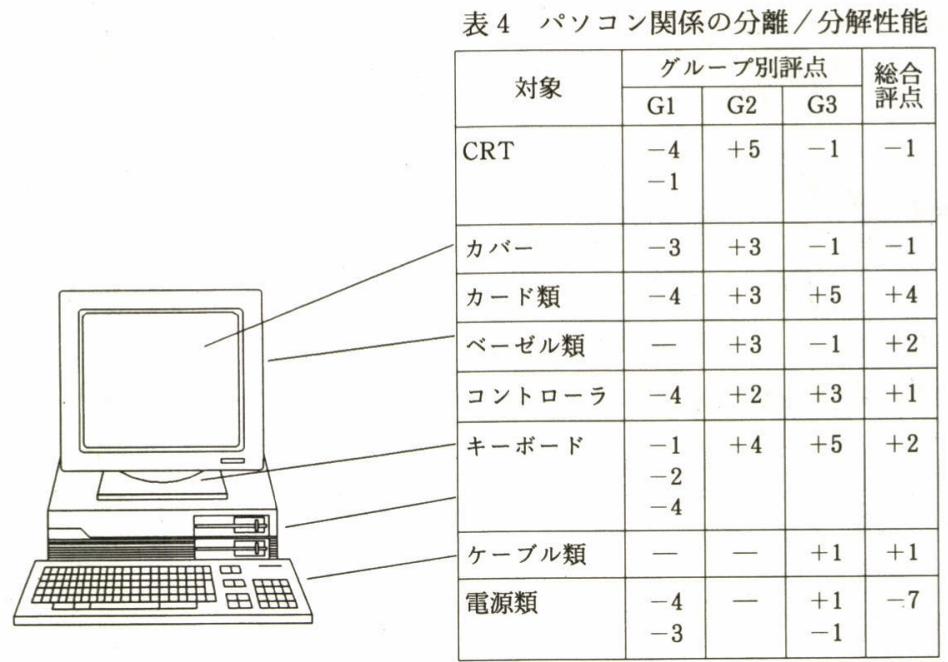

する方法などがある゙ $。$ この方法での全自動式と二槽式 の洗濯機の比較例を表 2 に示す。結合解除性では, 全自 動式が有利と判断される。

IBM では環境に配慮した製品（Environmentally Conscious Product) 開発基準作りに取り組んでおり, パソコンを対象に再資源化の問題点を調査した上で, 表 3 に示すような部品分離/分解性能に関する評点法を提 唱している7)。表 4 は，これに基づいてパソコン部品を 評価した結果を示す。

\section{6. ライフサイクルアセスメントの動向}

リサイクル法の制定以来, 製品アセスメントが話題に なっている。製品アセスメントの概念はきわめて大きく， 一般的には「製品生産者が生産を行う前に, 当該製品の 生産・流通・使用 - 廃棄・再資源化/処理処分の各段階 における安全や資源, 環境一の影響を調査, 予測および 評価し, 必要に応じて製品設計や生産法等の変更を行っ て影響の軽隇化を図る」ことと定義されている。このな かには，すでにテーマとして個別に進行している労働環 境の改善, 生産や使用時における省エネルギー, 環境污 染物質の削減等も含まれることになる。

一般的な工業製品に対する製品アセスメントの枠組み を生産 $\rightarrow$ 流通 $\rightarrow$ 使用 $\rightarrow$ 廃棄 $\rightarrow$ 再資源化/処理処分の流れ にしたがって図示したのが図 8 である。各段階ごとのア セスメント内容では廃棄物関連項目を重点に示したが, このほか全段階に対して安全性, 資源保全性および環境 保全性等が検討されなければならない。また，製品の取 扱者が適正に処置できるよう, 製品表示や取扱説明書の 妥当性についての考慮も必要である。表 5 にはアセスメ
ント項目の概要を例示した。

最近，製品が環境や資源に与える各種の負荷（以下， 環境負荷と呼ぶ）を，製品のライフサイクル全体にわ たって定量・評価しようとする試みが，ライフサイクル アセスメント (Product Life Cycle Assessment/Life Cycle Assessment：LCA と略す）として注目されて

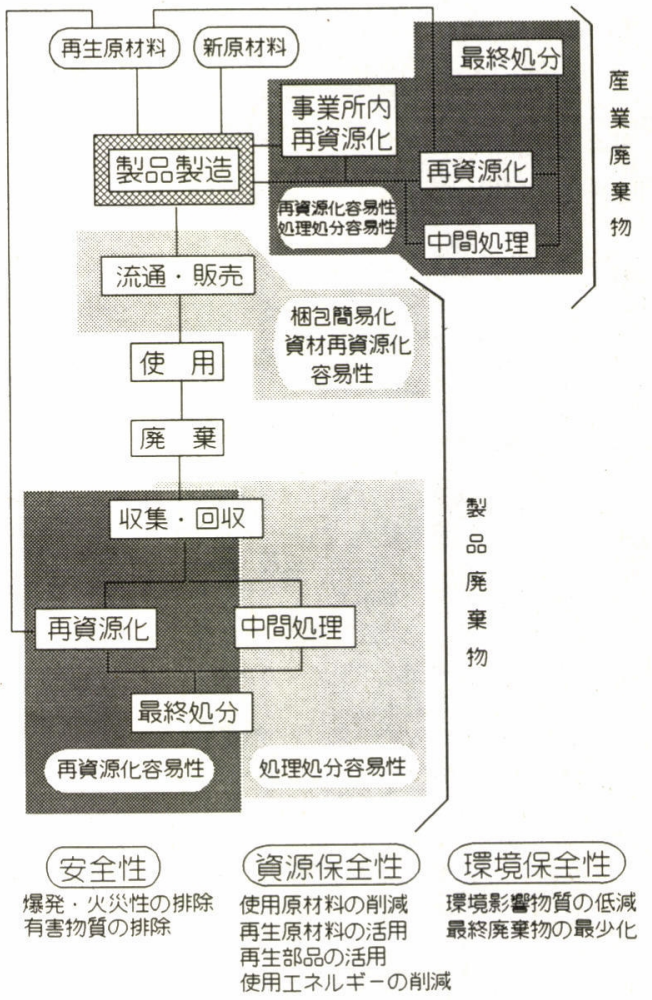

㘡 8 一般的製造業の廃棄物対応の枠組み（製品アセス メント) 
表 5 製品アセスメントの概要

\begin{tabular}{|c|c|c|}
\hline \multicolumn{2}{|c|}{ 廃棄物／全般 } & アセスメントの内容 \\
\hline \multirow{3}{*}{$\begin{array}{l}\text { 廃 } \\
\text { 㝤 } \\
\text { 荿 } \\
\text { 連 }\end{array}$} & 生 産 段 階 & $\begin{array}{l}\text { (1) 工程の收善や原材料, 製法の変更等による副産物や廃衰物の最少化 } \\
\text { (2) 廃棄物の再資源化や処理処分についての検討など }\end{array}$ \\
\hline & 流通眅売段階 & $\begin{array}{l}\text { (1) 梱包の簡易化等による資材の減量化 } \\
\text { (2) 再資源化にも配慮した材料選択など }\end{array}$ \\
\hline & $\begin{array}{l}\text { 再資源化/ } \\
\text { 処理処分段階 }\end{array}$ & $\begin{array}{l}\text { (1) 廃衰製品の収集・回収システムの検討 } \\
\text { (2) 再資源化処理あるいは通常の廃棄物の処理処分法に対する適応性の検討など } \\
\text { いわゆる適正処理困難物についての評価項目は，この中に包含される。 } \\
\end{array}$ \\
\hline \multirow[t]{3}{*}{ 全 } & 安 & 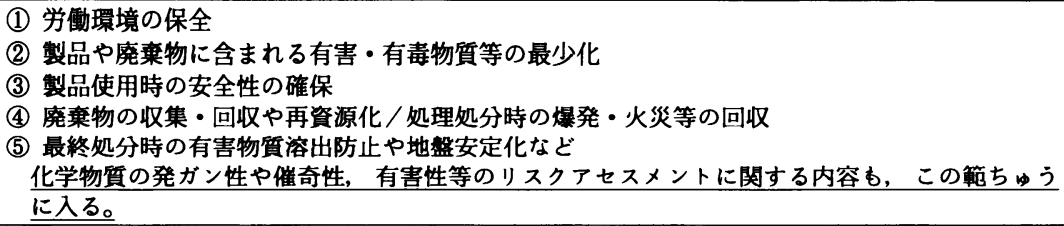 \\
\hline & 資源保全性 & $\begin{array}{l}\text { (1) 全段階における省エネルギー・省資源に対する配慮 } \\
\text { (2) 製造時における再生原材料の活用 } \\
\text { (3) 再利用のための再生部品の活用 } \\
\text { (4) 使用資源の削減に通じる製品の小型化, 長寿命化, 部品交換の容易化など } \\
\text { 生産から再資源化/処理処分にわたるエネルギーアナリシスもこの範ちゅうに入る。 }\end{array}$ \\
\hline & 環 境保全性 & 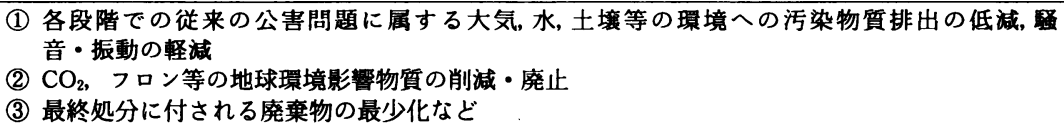 \\
\hline
\end{tabular}

いる。LCA は，製品アセスメントの評価項目をできる だけ定量化しようとするものであると理解することもで きよう。この際, 原材料の製造やそのための資源採取, さらには各段階間での輸送などを加え, 製品のライフサ イクルにわたるすべての行為が対象となる。LCA の実 施の目的は,

(1) 同一目的をむつ複数の製品間での環境負荷に関す る優劣の比較

(2) 製品改良による環境負荷の軽減効果の評価

（3）環境負荷の基準値や目標値に対する新製品等の達 成状況の判定

(4) 既存製品の改善方策の抽出

などであり，その目標とするところは製品製造業での製 品設計・生産法の改善や流通業者における品揃えの内容 変更などを促すこと, さらには消費者へ商品選択に当 たっての適切な判断資料を提供することなどである。

LCA については現在わが国を含め, 先進諸国でその 手法開発が活発に行われており，また国際標準化 （ISO） あ進められている。これまで実施または提案さ れている LCA の主なものを, 表 6 に示す。

ミグロスはスイス最大のスーパーマーケットチェーン であり, 包装材の選択を中心に, BUWAL 等の開発し た手法を用いて LCA を実施している。環境負荷のカテ ゴリーとしては, エネルギー消費, 大気污染, 水質污濁, 廃棄物量を取り上げ, さらに細目カテゴリーとして大気 污染では $\mathrm{NOx}$ や SOx, 非メタン $\mathrm{HC}, \mathrm{HCl}$, フロン,
$\mathrm{CO}_{2}$ を取り込んでおり, また廃棄物では一般系, 産業系 を区別して扱っている。最終的にはカテゴリーを統合化 して 1 つの指標とし; 「ェコポイント」単位で評価する。 オランダではライデン大学を中心にして, 汎用的 LCA 手法の開発を行っている。環境負荷のカテゴリー は, 表に見られるように広範に及び, 環境許容濃度や温 暖化ポテンシャルを用いたカテゴリーごとの統一指標づ くりを目指している。

フランスではエコビランが鉄鋼メーカーの依頼をうけ て LCA の開発を行った。NOxやSOx, SSなど細目力 テゴリーでの評価を目的としている。

先進的 LCA の事例としてはスウェーデン工業連盟な どによる方法が知られている。この手法はボルボ社で EPS (Environment Priority Strategies for product design）として設計に導入され始めている ${ }^{8)}$ 。

EPS では, 各種の素材・材料やエネルギー源, 大気 ならびに水質污染物質から土地利用や塗装, 溶接作業等 に至るまでの環境負荷の原単位 ELI (Environmental Load Index) をELU (Environmental Load Unit) 単位で整理し，これをライフサイクルでの使用材料やエ ネルギーの量, 面積あるいは作業点数等と積算集計する ことで ELV (Environmental Load Value) を求めて いる。表 7 は, その一例として GMT 複合材と亜鉛メッ キ鋼板のバンパーについての比較結果を示したものであ る。廃棄段階での ELV は再生可能量が多いため後者が 有利となるが, 使用時では軽量化によって前者の有利さ 
表 6 最近のライフサイクルアセスメント

\begin{tabular}{|c|c|c|c|c|c|}
\hline & 呼 & ミグロス & ライデン大学 & エコビラン & スウェーデン工業連盟 \\
\hline & 国 & スイス & オランタ & フランス & スウェーデン \\
\hline 開 & 発 主 体 & $\begin{array}{l}\text { スイス連邦環境森林景観 } \\
\text { 庁 (BUWAL), チュー } \\
\text { リッヒ連邦工科大学・ブ } \\
\text { ロセス冷東工学研究所, } \\
\text { ミグロス }\end{array}$ & $\begin{array}{l}\text { ライデン大学・環境科学 } \\
\text { センター, TNO 環境・・ } \\
\text { エネルギーグループ, 燃 } \\
\text { 料・資源庁 }\end{array}$ & エコビラン & $\begin{array}{l}\text { スウェーデン環境研究所 } \\
\text { (IVL), スウェーデン工 } \\
\text { 業連盟 }\end{array}$ \\
\hline 目 & 的 & 容器 - 包装材選択中心 & 汎用的な標準法 & 容器 - 包装材選択中心 & 沉用的な標準法 \\
\hline 力 & 資 源枯渴 & エネルギー源, 物質資源 & エネルギー源, 物質資嫄 & エネルギー源，物質資源 & $\begin{array}{l}\text { エネルギー源, 物質資 } \\
\text { 源, 食料, 生物資源, 土 } \\
\text { 地利用 }\end{array}$ \\
\hline $\begin{array}{l}\exists \\
\text { リ }\end{array}$ & 環 境 影 䈏 & 大気, 水 & 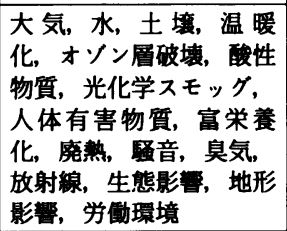 & 大気, 水 & $\begin{array}{l}\text { 大気, 水, 温暖化, 贁性 } \\
\text { 物質 }\end{array}$ \\
\hline & 廃拺物負荷 & 廃棄物（質量） & 廃棄物（質量） & 廃裹物（質量） & \\
\hline 指 & 統合化の程度 & 統一 & $\begin{array}{l}\text { カテコリー別（大気, 水 } \\
\text { 等） } \\
\end{array}$ & $\begin{array}{l}\text { 細目カテコリー } \\
\mathrm{NO}_{\mathrm{x}}[\mathrm{g}] \text { 等 } \\
\end{array}$ & 統一 \\
\hline 標 & 単 & エコポイント & $\begin{array}{l}\text { エネルギーEC [MJ], 大気 } \\
\text { UPA [m³], 温暖化 UGW } \\
\text { [mg-CFCl2eq 等 }\end{array}$ & $\begin{array}{l}\text { エネルギー }[\mathrm{MJ}], \mathrm{NO}_{\mathrm{x}} \\
{[\mathrm{g}] \text { 等 }}\end{array}$ & ELU \\
\hline & 用 & $\begin{array}{l}\text { ミルクパック, ヨーグル } \\
\text { 卜容器, 洗刜容器等の材 } \\
\text { 料選択 }\end{array}$ & なし & 缶の材料選択 & $\begin{array}{l}\text { ボルボのバンパー材料選 } \\
\text { 択 }\end{array}$ \\
\hline & 考 & $\begin{array}{l}\text { ・包装自体の加工, 充 } \\
\text { 填, 再使用は考虑せず。 } \\
\text { ・エコファクターは次 } \\
\text { 式, これに排出量等を積 } \\
\text { 算し合点してェコポイ } \\
\text { トとする。 } \\
\mathrm{EF}=\frac{1}{\mathrm{~F}_{\mathrm{K}}} \times \frac{\mathrm{F}}{\mathrm{F}_{\mathrm{K}}} \times 10^{12} \\
\mathrm{~F}_{\mathrm{K}} \text { : 国内最大許容排出 } \\
\text { 量 } \\
\mathrm{F}: \text { 国内実総排出量 }\end{array}$ & 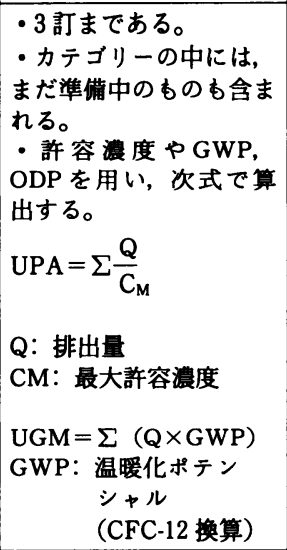 & & $\begin{array}{l}\text { - ELU で統合化 } \\
\text { ・3 訂まである。 }\end{array}$ \\
\hline
\end{tabular}

が強調される。総計の ELV は前者の方が小さく，環境 影響負荷では優れていると判断される。

ELI の設定では，環境負荷の回避のために支払う意志 のあるコストを中心に，環境影響の及ぶ範井，その地域 における規制の程度や問題の大きさ, 影響の持続性, 環 境影響における特定物質の寄与度合などが考慮され，表 8 のような数値が設定されている。

物質リサイクルは過度に強調すると,「何が本当に地 球に優しいのか」を見失う危険性をはらんでいる。リサ イクル型からさらに一歩進め, 環境・資源保全型製品設 計への指標づくりとして, 上記のような LCA 開発の努 力は今後む大いに推進されなければならない。

\section{7．環境保全を考虑した製品設計に関連する課 題}

リサイクルを含め，環境保全を考慮した製品設計に関 してはまだ緒についたばかりであり，表 9 に示すように 課題も多い。

これらのなかでは，まず環境保全型設計の普及と高度 化およびその評価が上げられよう。このためには実施例 を集積するととすに，評価方法を確立しなければならな い。評価に当たってはリサイクルの実効性の確保を前提 とし，また再資源化段階だけに注目するのではなく，製 品の生産・使用・廃棄・再資源化にわたるライフサイク 
(a)

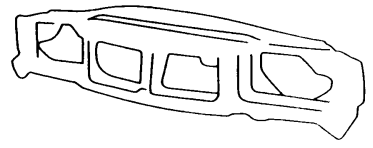

GMT每合财ハン八

蛪材使用 : $40 \mathrm{~kg}$ (0 3kg(t)廆菒) (b)

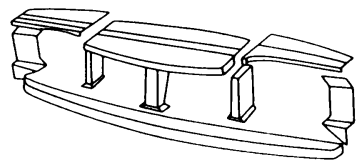

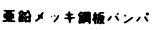

快使用 : 9 OKg ( $30 \mathrm{~kg}(2 \mathrm{c}$ 筮 (30kg(I) $60 \mathrm{~kg}$

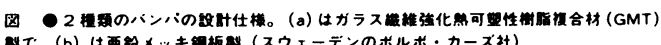

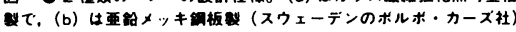

表 72 種のバンパーについての ELV の比較

\begin{tabular}{|c|c|c|c|c|c|c|c|c|c|c|c|c|c|c|c|c|}
\hline \multirow{3}{*}{ 品名 } & \multirow{3}{*}{ 材料工程 } & \multirow{2}{*}{\multicolumn{2}{|c|}{ 製 }} & \multirow{2}{*}{ 造 } & \multirow{2}{*}{\multicolumn{2}{|c|}{ 使 }} & \multirow{2}{*}{ 用 } & \multicolumn{3}{|c|}{ 裹 } & \multirow{2}{*}{\multicolumn{3}{|c|}{ 再生使用 }} & \multirow{3}{*}{$\frac{\text { 埋立 }}{\text { ELV }}$} & \multirow{3}{*}{$\begin{array}{l}\text { 小計 } \\
\text { ELV }\end{array}$} & \multirow{3}{*}{$\begin{array}{l}\text { 合計 } \\
\text { ELV }\end{array}$} \\
\hline & & & & & & & & \multicolumn{3}{|c|}{ 焼却 } & & & & & & \\
\hline & & ELU $/ \mathbf{k g}$ & $\mathrm{kg}$ & ELV & $\mathrm{ELU} / \mathrm{kg}$ & kg & ELV & $\mathrm{ELU} / \mathrm{kg}$ & $\mathrm{kg}$ & ELV & $\mathrm{ELU} / \mathrm{kg}$ & $\mathbf{k g}$ & ELV & & & \\
\hline \multirow{4}{*}{ 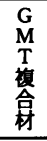 } & GMT & 1.58 & 4.0 & 6.32 & & & & -0.061 & 3.7 & -0.22 & -1.58 & 0.3 & -0.47 & & & 5.63 \\
\hline & ガソリン & & & & 0.64 & 29.6 & 18.94 & & & & & & & & & 18.94 \\
\hline & 压鉏成形 & 0.021 & 4.0 & 0.06 & & & & & & & & & & & & 0.06 \\
\hline & \begin{tabular}{|l|} 
小 $\quad$ 計 \\
\end{tabular} & & & 6.38 & & & 18.94 & & & & & & & & -0.69 & $\underline{24.65}$ \\
\hline \multirow{6}{*}{ 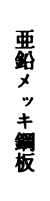 } & 亜鋂鐡板 & 1.02 & 9.0 & 9.18 & & & & & & & -0.92 & 9.0 & -8.26 & & & 0.90 \\
\hline & ガソリン & & & & 0.64 & 48.0 & 30.7 & & & & & & & & & 30.72 \\
\hline & スポット諳接 & 0.0028 & 48 & 0.13 & & & & & & & & & & & & 0.13 \\
\hline & 垌装 $\left(\mathrm{m}^{2}\right)$ & 0.082 & 0.6 & 0.05 & & & & & & & & & & & & 0.05 \\
\hline & $\begin{array}{l}7 \\
7\end{array}$ & 0.042 & 9.0 & 0.36 & & & & & & & & & & & & 0.36 \\
\hline & $\begin{array}{ll}\text { 小 } & \text { 計 } \\
\end{array}$ & & & 9.72 & & & 30.7 & & & & & & & & -8.26 & $\underline{32.16}$ \\
\hline
\end{tabular}

表 8 ELI (Environmental Load Index) の例

\begin{tabular}{|c|c|c|c|c|c|c|c|c|c|}
\hline $\begin{array}{l}\text { 原料 } \\
\text { 素材 }\end{array}$ & ELU/kg & 料 & $\begin{array}{c}\text { ELU / } \\
\mathrm{kg}\end{array}$ & エネルギー & $\begin{array}{c}\text { ELU / } \\
\mathrm{kg}\end{array}$ & $\begin{array}{l}\text { 大気污 } \\
\text { 染物質 }\end{array}$ & $\begin{array}{c}\text { ELU / } \\
\text { kg }\end{array}$ & $\begin{array}{l}\text { 水質污 } \\
\text { 染物質 }\end{array}$ & $\begin{array}{c}\text { ELU / } \\
\text { kg }\end{array}$ \\
\hline Co & 12300 & \multirow{2}{*}{ 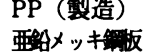 } & 0.97 & 石油 & 0.33 & $\mathrm{CO}_{2}$ & 0.04 & BOD & 0.0001 \\
\hline $\mathrm{Cr}$ & 221 & & 1.02 & ガソリン & 0.64 & $\mathrm{CO}$ & 0.04 & COD & 0.00001 \\
\hline $\mathrm{Fe}$ & 0.38 & （製造） & -0.92 & 石炭 & 0.28 & $\mathrm{NO}_{\mathbf{x}}$ & 245 & 油分 & 0.00001 \\
\hline Mn & 21 & \multicolumn{2}{|l|}{ （再生） } & 電気 （/MJ） & 0.014 & $\mathrm{~N}_{2} \mathrm{O}$ & 0.6 & Phenol & 1 \\
\hline Mo & 4200 & 生産工程 & ELU/kg & & & $\mathrm{SO}_{\mathrm{x}}$ & 6.03 & PCB & 10000 \\
\hline $\mathrm{Ni}$ & 700 & & 0042 & 土地利用 & $\mathrm{ELU} / \mathrm{m}^{2}$ & $\mathrm{HC}$ & 10.2 & DIOXIN & 100 \\
\hline $\mathrm{Pb}$ & 262 & \multirow{3}{*}{$\begin{array}{l}\text { 鐵板プレス } \\
\text { フォームプレィ } \\
\text { 塑装 }\left(/ \mathrm{m}^{2}\right)\end{array}$} & $\begin{array}{l}0.042 \\
0.051\end{array}$ & 都市地域 & 2.91 & PAC & 600 & $P$ & 2 \\
\hline $\mathrm{Pt}$ & $4.2 * 10^{7}$ & & $\begin{array}{l}0.051 \\
0.082\end{array}$ & 森林地域 & 1.05 & Aldehyde & 20 & $\mathrm{~N}$ & 10 \\
\hline $\mathrm{Rn}$ & $4.2 * 10^{7}$ & & $\begin{array}{l}0.082 \\
0.0028\end{array}$ & その他 & 0.98 & $\mathrm{Hg}$ & 10 & $\mathrm{Al}$ & 1 \\
\hline Sn & 4200 & \multirow{2}{*}{$\begin{array}{r}\text { スホット卜溶接 } \\
(/ \text { 点) }\end{array}$} & 0.0028 & & & F & $1 * 10^{-7}$ & As & 0.01 \\
\hline V & 42 & & 0.021 & & & & & $\mathrm{Cd}$ & 10 \\
\hline 石油 & 0.168 & \multirow{3}{*}{\multicolumn{2}{|c|}{ 押出成型 }} & & & & & $\mathrm{Cr}$ & 0.5 \\
\hline 石炭 & 0.1 & & & & & & & $\mathrm{Hg}$ & 10 \\
\hline & & & & & & & & $\mathrm{Pb}$ & 0.01 \\
\hline
\end{tabular}

\section{表 9 環境保全型製品設計に関連する課題}

1）環境保全型設計の具体的実施例の集積

2）環境保全型設計製品の評価手法に関する研究

3）ライフサイクル分析のための基礎データの整備

4）第 1 種製品以外にも適用可能な

環境保全型設計の指針と基本的マニュアル

5）生産から再資源化にわたる各段階での

システムの整備と技術開発

6）再生資源の高品質化と利用の拡大

ルでの判断が求められよう。このための基礎デー夕の整 備が望まれる。こうした点を通じて, 物質回収かエネル ギー回収かを含め,「何が本当に環境にやさしいのか」 を明らかにしていかねばならない。次に望まれるのは環 境保全型設計の裾野の拡大である。第 1 種製品ばかりで なく，他の製品に対しても環境保全型設計の導入を促進
するために指針やマニュアル等を整備することが重要で あろう。

リサイクルが高度に機能するためには, 社会システム の整備とならんで, 図 9 に示す各段階での技術開発やシ ステム創りが肝要である。再資源化処理や再生等におけ る静脈産業での技術は, 動脈側と比較すれば遅れをとっ ており, 今後の研究開発の余地が多い。また, 多岐にわ たる廃棄物からのこうした再資源化技術は，動脈よりさ らに複雑にして高度なハイテク技術とみることもできる。 対象製品の製造業も含め, 選鉱等を通じて関連技術に長 （た）けた素材産業を中心に，技術開発へのより積極的 な取り組みが望まれる。

リサイクルの輪は再生資源の活用がなければ完結しな い。現状では, とくにこの部分のつながりが悪く, 進展 が遅れている。 Reduction, Reuse, Recycle の 3 要素 


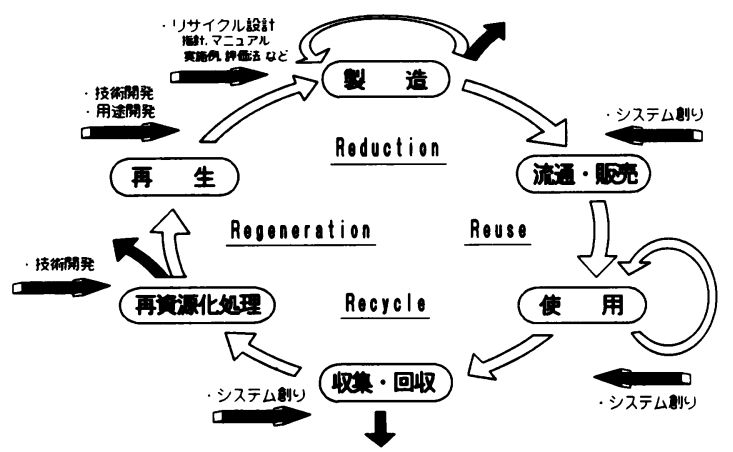

図9 リサイクルリングにおける4つの R

で呼ばれるリサイクルリングに Regeneration（再生） を加えて,この点を強調しておきたい。材料の高機能 化・多様化の中で再生は困難さを増しているが, 再生資 源の使用拡大には, 用途開発すさることながら, より高 品質な素材・材料への再生が鍵となる。なお, 再生資源 の利用拡大は，技術のみでは対処できない側面をむって いる。再生資源使用に対する税制優遇措置や JIS 化など の誘導政策も必要になろう。

システム創りにおいては廃棄製品の収集・回収す含め, 製造段階での産業廃棄物や流通段階での使用資材などに ついての再資源化および再生資材の還流, さらに使用段 階では中古品や中古部品の利用に関する対応が重要であ る。すでに自動車中古部品については，官民協力のもと での情報ネットワークの構築に向けた動きす報じられて いる。

\section{8.あとがき}

今後の資源リサイクルの進展には，それに関連する技 術開発のみならず, 関連する人々の意識の問題む大きな
影響を与えよう。とくに資源リサイクルのデシジョンポ イントを握っている製品設計者の役割は大きい。工業製 品は一般に数年から十年を越える寿命を持っている。こ のタイムラグを考えれば, 現時点で環境保全型設計を考 慮することが遅過ぎるとはいえても，早過ぎることはな い。消費者の購買選好に製品のリサイクル性が組み入れ られる時代に突入しようとしている。技術者にとって難 問ではあるが, チャレンジのしがいのあるテーマである。

\section{考文嗝}

1）永田勝也：地球環境問題からみた廃桻物再資源化につ いての一考察, クリーンジャパン, No. 80, pp. 26-31 (1990)

$2 ）$ 永田勝也：製品設計とリサイクル，精密工学会誌， Vol. 58, No. 1, pp. 18-23 (1992)

3）鶴原吉郎：リサイクルを目指した解体しやすい設計一 部品を統合化し, 結合法を工夫一, 日経メカニカル, pp. 54-60 (1991)

4) H. -H. Worf : Technology and Strategy of Automobile Recycling, 日独共同・廃車リサイクルを考え るセミナー, NTS (1991)

$5 ）$ 元田欽也：廃衰物の処理容易性について, クリーン ジャパン, No. 35, pp. 17-25 (1982)

6) 原製品の再資源化適正化調查（適正化製品の設計）報 告書, クリーンジャパンセンター（1982）

7) 内藤博, 坂本茂實 : 製品開発における環境影響評価 (I) （リサイクリングに対する検討）製品廃棄物処理現場か らみたパソコン製品設計の問題点, 第 2 回廃棄物学会 研究発表講演論文集, pp. 113-116 (1991)

8) Environmentally Compatible Product Development with the EPS System - A System for Calculating Environmental Impact -, Volvo Car Corporation \& etc., (1991) 


\title{
Recyclability and Life Cycle Assessment on the Product Design
}

\author{
Katsuya Nagata \\ Professor of Waseda University \\ ( 3-4-1, Ohkubo, Shinjuku-ku, Tokyo 169 Japan)
}

\begin{abstract}
s
The environmental protection and the resouce conservation are now major issues all over the world. On one side, waste management, especially, material recovery from the old products is one of the key factors solving these problems. On the other side, the recycling-oriented design for new products is an important factor.

In this paper, recyclability and life cycle assessment on the product design are discussed on the following items,

(1) features of the various recycling systems,

(2) essential points of recycling-oriented design,

(3) concept and examples of the life cycle assessment,

(4) remaining issues on the environment-friendly design and production measures.
\end{abstract}

Key words : product design, recycling, recyclability, life cycle assessment, material recovery 